\title{
Attitude towards Parents Who Still Practice the Cheng Beng Tradition from a Biblical Perspective
}

\author{
Anna Munanto, Yanto Paulus Hermanto, Tonny Andrian Stefanus \\ Sekolah Tinggi Teologi Kharisma - Bandung, Indonesia
}

\begin{abstract}
Cheng Beng is a ritual performed by ethnic Chinese people to pray for their ancestors who have passed away. Since many Chinese descendants have become Christians, the Cheng Beng tradition often becomes a difference of opinion between families who have embraced Christianity and those who are nonChristians. Therefore, this research is intended to provide insight for Christians to be faithful towards their religion and respectful towards their parents who still practice the Cheng Beng tradition. For this reason, research is carried out that focuses on the principles of evangelical theology to address this matter. This study explores practical ways of behaving, so that it can be implemented for all members of the congregation.
\end{abstract}

Keywords: Cheng Beng, Chinese tradition, Christian Attitude

\section{INTRODUCTION}

\section{Cheng Beng tradition}

I $\mathrm{n}$ an attempt to prevent the rise of communism during the Soeharto era, Indonesian people were encouraged to embrace a religion as part of their lives. Chinese people generally believe that being part of a religion that is officially recognized in Indonesia could protect them from an unfair treatment from the government. They believe that being a Christian eliminates the stigma of being Chinese, given that Christianity is largely associated with Western, instead of Eastern, culture. For the Chinese community which was subjected to forced assimilation and experienced cultural oppression, Christianity offered a new identity (Suwignyo, 2020).

As such, many Chinese people have sent their children to Christian schools since the New Order regime. Eventually, these children embraced Christianity until their adulthood, while their parents continued to follow Buddhism or Confucianism instead of converting to the religion of their children. In fact, parents often disallow one of their sons to convert to Christianity out of worry that if all of their children are Christians, no one would pray for them when they pass away (Sutanto, 2009).

The Cheng Beng tradition which is celebrated every year is known as Tomb-Sweeping in English, in Mandarin it is called Qing Ming, while in Hokien it is called Cheng Beng. 'Cheng' and 'Beng' mean 'clean' and 'bright', respectively (Suharyanto \& Matondang, 2018). The Cheng Beng tradition is an activity that people with Chinese heritage do based on the teachings of Confucianism, which preaches devotion and respect for parents and ancestors. The descendants of those who have passed celebrate Cheng Beng to serve the needs of their ancestors in the afterlife. They do this by praying, offering food at the altar, cleaning graves, and sending prayers (Suharyanto \& Matondang, 2018).

Cheng Beng is celebrated every year on April 5, or April 4 in a leap year. Generally, the time for prayer is between 10 days before April 5 and 10 days afterward (Vistari, 2017). For ethnic Chinese, the Cheng Beng tradition is very important due to their belief that the spirits of their departed ancestors can protect their descendants from calamities and provide good fortune for them. In addition, the respect for ancestors carried out by Chinese people is highly motivated by filial piety (children's obedience to their parents) (Kandars, 2018).

Cheng Beng also aims to strengthen the relationship between family members, hence it is often used as a family reunion event. Those who are from out of town or abroad would return to visit the graves of their parents and ancestors once a year during Cheng Beng (Kandars, 2018). On Cheng Beng holidays, the whole family gathers at the graves of their parents or ancestors. The first thing they do when they arrive at the tomb is to clean and repair the tomb as the door of the deceased is believed to be opened during Cheng Beng, making the cleaning and repairing of the tomb possible. Next, the prayer ceremony is held by serving food in the form of side dishes, fruits, cakes, and drinks, which is what the deceased usually enjoyed to eat when they were alive. This prayer ceremony is usually led by one of the elders who has been appointed by the family (Kandars, 2018).

Following the serving of food, everyone present is given a certain amount of incense to start praying. After the conclusion of the prayer, the Hio is stuck on the altar especially made for the prayer ceremony. After all the family members have finished praying, they burn gold, silver, money, clothes and daily supplies, which were all made of paper in order to make them easy to burn. Currently, many items that people commonly use for prayer are sold in shops. These items, mainly made of paper and sticks, include shoes, sandals, cell phones, computers/laptops, clothes and banknotes in both rupiah and dollars. The purpose of burning these items is to send daily necessities and money for the ancestors to use in the afterlife.

\section{Cheng Beng tradition and Christianity}

There have been ongoing debates among Christians about how certain traditions passed down from parents are to be understood or practiced within a Christian perspective. The main problem is the belief that there are several ceremonies or 
practices in Chinese traditions that are contrary to Christian teachings. Hence, many Christians are hesitant to follow Chinese cultural traditions for fear of being considered sinful.

Another common problem is that not every member of a family is Christian. Hence, differences of opinion can even lead to conflicts and fights because of the different beliefs held by each family member. This is especially true in a case where the parents still hold strong Chinese traditions and are Confucian, while their children are Christian. Parents consider their children no longer filial, because they refrain from performing ceremonies or pray to their ancestors. With this conflict, parents certainly do not want to be asked to choose Christianity and can even develop resentment towards Christianity.

Therefore, this research aims to address the following question, "What is the attitude towards parents who still hold the Cheng Beng tradition based on the principles of evangelical theology?" Specifically, the purpose of this study is to help Christians in better understanding how to behave towards parents who still adhere to the Cheng Beng tradition, based on the Christian principles.

\section{METHOD}

The authors used a qualitative research approach. The authors collected, read, and interpreted various books and journals related to the research question. The authors obtained theories and insights from various libraries, which allowed them to address the research problem.

The authors also adopted a phenomenological perspective to explore the Cheng Beng tradition from the point of view of a Christian family. The findings of this study provided evidence of whether and how this tradition is consistent with evangelical theology.

In this respect, the Bible was used as the core to draw the conclusions of this study. Thus, this study provides guidance to Chinese Christians in relation to how to have the right attitude towards family, especially towards their parents who still practice the Cheng Beng tradition. The data analysis in this study was conducted based on prior literature in this area and the knowledge derived from the Bible.

\section{RESULTS AND DISCUSSION}

\section{Cheng Beng Tradition and Christianity}

Family relations within the Chinese family are highly prioritized and upheld. Children are expected to be devoted to their parents, and this devotion to their parents continues even after their parents have passed away. To maintain this relationship, living family members have an obligation to continue to demonstrate their devotion to their deceased parents. Hence, the conflicting philosophies between Cheng Beng tradition and the teaching of Christianity might pose a problem for the Chinese Christian families (Chuarsa, 2019).

Worshiping ancestral spirits, for Chinese people, is a way for people to express their devotion to their parents after they have passed away. According to the Chinese beliefs, the spirits of people who have died can have relationships with people who are still alive; offering protection and care for their family. Thus, Chinese culture states that this love for parents is part of love for their ancestors (Tedjo, 2011).

Some Christian religious leaders have started to provide a lot of leeway to Chinese people who follow Christianity, in order to allow them to selectively take part in practicing this Chinese cultural tradition. Unreasonable things or myths from Chinese beliefs or traditions, however, cannot be accepted and are prohibited for Christians. The Cheng Beng tradition, or what is known as the tradition of 'praying the grave', is one of the traditions that Christians are very much shunned, because in doing so, one has to burn incense while bending over in front of the graves of the ancestors and putting fruit, flowers, and other food in front of the ancestor's grave. The whole process is categorized as a form of worshiping the spirits of the dead, whereas in the general understanding of Christians, worshiping anything other than God means violating God's commandments and therefore, is considered a sin (Chuarsa, 2019).

There is also a belief that the souls of those who have passed do not need to be prayed for because it is God's own business. The prayers delivered will no longer be of use to those who have died (Krisnando, Objantoro, \& Darmawan, 2019). Being a Christian means giving your life completely to God by opening your heart and accepting God as your Savior (Kii, 2018). In Deuteronomy 18: 9-11 it says: "When you enter the land that the Lord your God has given you, then you must not learn to behave in accordance with the abominations that the nations have committed. Among you, do not find anyone who offers his son or daughter as a sacrifice in the fire, or someone who is a witchcraft, a fortune teller, a scholar, a magician, a charmer, or someone who asks a spirit or asks for directions to a dead person.”(Kii, 2018). Thus, for Christians, the rituals related to worshiping the ancestors are prohibited. The attitude that should be shown as a Christian is to ask other people, who can usually be found at the Klenteng, to perform the Cheng Beng prayer ceremony, or ask their non-Christian relatives to do so.

The Confucian religious community and all its religious institutions in Indonesia have existed since ancient times, which is driven by the arrival of immigrants or Chinese traders to Indonesia. Confucianism is a term that emerged as a result of the political situation in Indonesia. Confucianism is commonly confused with its meaning and essence with Confucianism as a philosophy. Confucianism emphasizes noble morals by maintaining good relations between people in the sky and humans on earth. Adherents are taught to remember their ancestors as if their spirits were present in this world. This teaching is a philosophical and ethical arrangement that teaches how humans behave (Tedjo, 2011).

Basically, Confucianism teaches about morality that every human should possess in accordance with the concept of "Hau". The concept of "Hau" is the basis for good relations 
between families and communities and the state. This concept was used by Confucius to regulate the social order of society, so that in subsequent developments, "Hau" was not only understood in family or community relationships, but also between people living with their ancestors (Firdaus, 2020).

Chinese people believe that the relationship between parent and child is not severed by death, so that the aspect of worshiping parents or ancestors is a natural part of life in Chinese society, including the cycle of birth, marriage and death (Gondomono, 1996). If Chinese people fail to follow this teaching, then they are considered as "Put Hau" people. The term "Put Hau" is related to the concept of happiness and salvation, which is why in the Chinese community, people, especially men, are very obedient and loyal in worshiping their ancestors. Thus, one of the major obstacles for Chinese people, especially men, in practicing Christianity is their obligation to lead the worship of the spirits of their ancestors and their responsibility to uphold tradition (Firdaus, 2020).

The Confucian teachings teach more about ethics (philosophy) than the problem of human relations with God, and develop in three aspects (Tedjo, 2011). First, worship of Allah. God in the teachings of Confucianism is the One and Almighty God. However, there is no teaching about God being a permanent God and in fact, the God that they know in the teaching of Confucianism is able to communicate with them. The 8th and 9th of the month of Chinese New Year is the time of prayer, which is called the prayer of Allah.

Second, worship of godly people. This worship is the main stream in Confucian thought. In the beginning no one worshiped Confucianism, but over time there were some kings who adopted the Confucian thought, so that Confucianism was raised equal to God. Third, worship of ancestral spirits. Confucius argue that family is a unit in society. If every family is stable, as a result, society and the country are also stable. In order to maintain the stability of society and the country, followers of Confucianism move the teachings of devotion and worship to ancestral spirits.

Taken together, in the Confucian teachings there is more emphasis on a child's filial piety to his parents or to his ancestors, rather than devotion to God. On the other hand, in Christianity, Jesus teaches not only acts of filial piety to parents, but also how we must respect God. Also, children are obliged to respect their parents while they are still alive (Tedjo, 2011).

\section{Misunderstanding of Cheng Beng}

Cheng Beng as a part of the Chinese tradition, is one of the ways to show devotion to people's ancestors. Chinese people firmly believe that the spirits of the ancestors will continue to help people who are still living in the world. Thus, if those who are still alive do not respect the condition of graves, or pay respect to the ashes of their ancestors and send offerings to them, it can cause a bad fortune to them. A possible reason for this is that there is a view that if the spirits are not prayed for, the spirits will become evil spirits (Kiawan, 2018).
Worship is a part of most world religions, in this case Christianity, which has a hierarchical concept in seeing the dimensions of the world: the supernatural (God, or the unseen), culture (humans), and nature (which is not human). The supernatural (God, the unseen) is in a higher position than culture (humans). The relationship between the supernatural (God or the unseen) and culture (man) is always characterized by a 'worship' relationship. In this line of thought, 'ancestral reverence' is then imagined as 'ancestor worship' (Chuarsa, 2019).

For example, during the Cheng Beng ceremony, before the prayer ceremony begins, various kinds of food are provided, which usually consists of fish (sea), pork (land), fruits, cakes, coffee and tea which are placed in front of the parents' graves. The tombs of Chinese people generally have small altars for the purposes of prayer and a place for these foods. Often this is imagined by Christians as food that is offered to the dead. However, if it is viewed from the perspective of the Chinese people who carry out the ritual, food that is placed in front of the tomb or altar is food that was liked by the deceased during life. Thus, the food became a symbol of the children's devotion to their parents. That is, the children still provide their parents with favorite food, even though they have passed away.

Another thing that is often problematic is the attitude of bowing in front of a tomb or altar, which is defined as worship of ancestors or the dead. In Chinese culture, bowing in front of an ancestral grave or altar should be interpreted as a symbol of respect, rather than worship. This is different from, for example, the Jewish tradition which links the bowing of the body to 'worship' because it was the custom of idol worshipers to bend over before their idols (Chuarsa, 2019).

China, Japan and Korea have different concepts about bowing. They bowed to pay homage to the person they respected. Even in many places such as restaurants, shops and public places, they often bow to every customer who stops by their shop as a tribute. The Hebrew term for bowing before idols is Hishtachavayah, which is different from the Shakkhah, which is bowing in honor of the king, parents, and other respected persons. In the English and Indonesian versions of the Bible there is no difference in the terms Shakkhah and Hishtachavayah, so it is generally accepted by Christians that bowing is the same as worship. Even though in Christianity itself, when worshiping God, bowing movements are rarely used (Chuarsa, 2019).

In Chinese Tradition, during prayer ceremonies, they always use Hio, where the function of the Hio is similar to incense, which is to give off a fragrant fragrance when it is burned to create a sacred and quiet atmosphere. The use of this incense or incense is often imagined by some Christians as a form of worship because it compares with rituals in the Bible that use incense as a means of prayer. Incense is mentioned in the Book of Family 30: 1 "You shall make an altar, a place for incense burning, and you shall make it of acacia wood." The burning of incense is also a description of the prayers of the 
faithful, mentioned in Psalm 141: 2 "Let my prayer be for you like an incense offering, and my hands are raised like a sacrifice at evening."

In the New Testament, Luke's gospel records in Luke 1: 10-11 that many people gathered outside and prayed. It was the time of burning incense. And behold, to Zechariah an angel of the Lord was standing at the right of the altar of incense. Before Jesus was crucified, God's people used incense to sanctify, bless and scent, and the rising smoke smelled sweet to God. By looking at the existing phenomena as a Christian, one should be able to respect and accept people who perform the Cheng Beng ceremony with the correct understanding. If circumstances force you to pay homage to your ancestors, do not bow your head like in a prayerful manner. Likewise, if offered a Hio for prayer, it can be said subtly that the Hio is not needed.

Attitudes toward Parents Who Still Adhere to the Cheng Beng Tradition Based on Evangelical Theology Principles

First, an Attitude That Follows the Biblical Teachings.

Christians who come from Chinese ethnic backgrounds often face a dilemma when faced with certain cultural norms. Is Chinese culture compatible with Christian faith? Often Christians are labeled as people who have forgotten about their ancestral cultural heritage or, more often than not, they are deemed to no longer respect their parents who have died because they do not want to follow all traditions or customs in their entirety.

In determining the attitude of a Christian towards certain customs, the full orientation of the attitude should be solely focused towards God and His will. Therefore, it is necessary to consider the following issues: (Simatupang, 2014)

First, is the tradition a tool to praise and glorify Allah?

Second, does the tradition invite you to become idolaters?

Third, does the tradition reflect God's holiness?

Fourth, does the tradition love humans and have human values?

The Lord Jesus was not against customs, for example He was also circumcised in accordance with the customs of the Jews, but on the other hand, Jesus was so opposed when these customs became more prominent than the Word of God, as it is said in Matthew 15: 3: "Why do you violate the commandments for the customs of your ancestors? "(Simatupang, 2014).

Lord Jesus wanted to state that the main priority of people was to obey God's commandments, which transcends all customs. This means that if there are customs that are not in accordance with the Word of God, it is advisable not to do them. Thus, the Bible still has to be the basis for Chinese Christians.

The question is, is it permissible for Christians to celebrate Cheng Beng? Christians should regard this celebration as a social culture. In other words, Cheng Beng culture is a celebration to honor or remember ancestors, clean tombs and gather with the whole family. This perspective and way of thinking do not contradict the Bible. In fact, Christians should be positive and not stay away from their parents or other siblings who are still alive and adhere to the traditions of the Confucian religion.

In Ecclesiastes 7: 2, it is better to go to the house of mourning than to go to the feast, because in the mourning house is the end of every human being; the living should pay attention to it. Solomon wanted to explain that it is better to go to see a dead person than to a party. By visiting someone who has died in a funeral home or grave, the end of a human's life can be seen so that the viewer can realize that life in this world is temporary and in doing so, people can further dedicate their life to God. Another thing that Solomon wanted to convey was that when he was in the funeral home, it was not to worship or pray for the dead, but instead to serve as a reflection for the living to be wiser in earthly life. That one day they too will experience the same thing, which is why they should fill their days with activities that are good.

If Cheng Beng, as a religious culture, has been infiltrated or mixed with worship of the gods and goddesses, it is better for Christians not to be involved in the ceremony, because the ceremony is against the Word of God. In the Book of Deuteronomy 18, God spoke through Moses, saying that when the Israelites had entered the land of Canaan, no one should find anyone asking for directions to the dead. For whomever does it, God will chase them away. (Deut. 18: 9-12) Likewise in Leviticus 19:31 says, "Do not turn to spirits or fortune tellers; do not seek them and become unclean because of them. I am God, your God. " The meaning of these verses is very clear that as God's people it is not permissible to ask for directions to the dead or to seek their spirits. Thus, during Cheng Beng, as a Christian we should not pray for sustenance for the departed ancestors. It is better if we pay homage by cleaning the grave, expanding it, and praying for those who are still alive to receive salvation from God. Thus, prayer and worship are only directed to Allah.

So clearly these verses affirm that only God is worthy of worship. However, if as a Christian you are forced to perform the ritual of worshiping the gods and goddesses, it is better if this is left to people who are used to doing it. If there are still people in the family who are Confucian, it is better if this ceremony is left to them, but if the whole family has embraced Christianity, this practice is no longer necessary.

Second, Attitudes That Maintain Good Relationships with Parents.

In Deuteronomy 5:16 it says, "Honor your father and mother, as the Lord your God commanded you, so that you may have a long life and be well in the land that the Lord your God has given you." Matthew 15: 4 also conveys the same message; "For God says, Honor your father and your mother; and again: Whoever curses his father or mother is punished by death. " So in the Old and New Testaments God always want all 
Christians to respect their parents. However, the Bible also give limits in order to prevent being directed to do things that contradict the Bible itself. By honoring your parents God promises to give you a long life. Even in the New Testament there is a concept of punishment for people who do not respect their parents (Hermanto, Christine, Mukti, \& Santoso, 2021).

In connection with the Cheng Beng celebration, if there are still living parents who are Confucian, as a service to their parents, it is appropriate for Christians to celebrate, respect and show love for the living parents. This is intended to avoid a problem in the family. If suddenly a tradition which has been passed down from generation to generation is rejected by their children who have only been Christian for a few years, it will certainly cause displeasure to the parents.

Thus, as a Christian, they should show tolerance to people of different beliefs and not insist that what they believe is the only truth, even though in essence the Lord Jesus is the truth. However, with such an attitude, you will be able to maintain good relationships, especially with your parents. Maybe later when the Cheng Beng ceremony is over, and in a more relaxed and neutral atmosphere, as Christians, we can start giving input about who the Lord Jesus is and start evangelizing them. Because when parents become Christians, this dispute about Cheng Beng is less likely to happen again.

It is biblical to be kind and respectful to parents who are still living, even though they still have other beliefs. There is a saying, if you want to give delicious food, give it while the parents are alive, not after they die. Give a house to parents, give it during his life, not a house when the parents have died. Do not let it be the other way around that when they are still alive they are never treated well or receive gifts (Sutanto, 2009).

\section{CONCLUSION}

Christian people should show Christianity by showing the teachings of love which is the main commandment of Jesus. Apart from love, Christians need to have wisdom to keep doing the right thing in dealing with differences in beliefs, especially when it comes to parents who still celebrate Cheng Beng. Things that do not contradict the Bible, such as coming to the grave, cleaning and expanding the tomb, and praying for the family who are still alive, should continue to be celebrated. In this way, it is hoped that a healthy relationship can be maintained with the parents where they feel valued and respected.

\section{REFERENCES}

[1] Chuarsa, I. (2019). Reimagining Chinese Cultural Tradition: The Quandary between Chinese Indonesian Cultural Tradition and Christian Dogma in Indonesia. Yogyakarta: Sekolah Pascasarjana UGM.

[2] Firdaus, Y. F. (2020). Peran orang-orang Tionghoa dalam pekabaran injil: Kajian historis terbentuknya jemaat Tionghoa di Jawa Barat. Jurnal Abdiel: Khazanah Pemikiran Teologi, Pendidikan Agama Kristen dan Musik Gereja, 4(1), 77-97.

[3] Gondomono. (1996). Membanting Tulang Menyembah Arwah; Kehidupan kekotaan masyarakat China. Depok: Fakultas Sastra Universitas Indonesia.

[4] Hermanto, Y. P., Christine, C., Mukti, G. H., Santoso, C., \& Prayitno, Y. P. A. (2021). Sikap Hormat Anak Terhadap Orang Tua Berdasarkan Prinsip Alkitab. Evangelikal: Jurnal Teologi Injili dan Pembinaan Warga Jemaat, 5(1), 80-87.

[5] Kandars, F. (2018). Kajian Soteriologi terhadap ritual Cheng Beng yang dilakukan oleh anggota jemaat GMIT Pola Tribuana Kalabahi. Universitas Kristen Satya Wacana.

[6] Kii, N. I. (2018). Peran guru PAK dalam mengatasi penyembahan berhala (Doctoral dissertation, Sekolah Tinggi Teologi Injili Arastamar (SETIA) Jakarta).

[7] Kiawan, H. (2018). Keterlibatan Katolik-Tionghoa di Kota Semarang bagi Panca Tugas Gereja. Jurnal Teologi (Journal of Theology), 7(1), 45-62.

[8] Krisnando, D., Objantoro, E., \& Darmawan, I. P. A. (2019). Konsep Teologi Injili Tentang Roh Orang Mati. Evangelikal: Jurnal Teologi Injili dan Pembinaan Warga Jemaat, 3(1), 90-99.

[9] Simatupang, N. (2014). Gereja yang peduli pada budaya.

[10] Suharyanto, A., \& Matondang, A. (2018). Makna upacara Cheng Beng pada masyarakat etnis Tionghoa di Medan. In Prosiding Seminar Nasional Pakar, 21-26.

[11] Sutanto, S. (2009). Hormatilah ayah dan ibumu.

[12] Suwignyo, D. (2020). Identitas ketionghoaan jemaat Tionghoa GKT Hosana 华人会众的中华性身份认同. Century：Journal of Chinese Language, Literature and Culture, 8(2), 46-55.

[13] Tedjo, T. (2011). Mengenal agama Hindu, Budha dan Kong Hu $\mathrm{Cu}$. Bandung: Pioner Jaya.

[14] Vistari, L. (2017). Makna Ceng Beng dalam Perspektif Budha Dharma. Jurnal Pelita Dharma, 1, 87-96. 